Prepared for the U.S. Department of Energy

under Contract DE-AC05-76RL01830

\title{
Analysis of Hanford-based Options for Sustainable DOE Facilities on the West Coast
}

\section{WM Warwick}

June 2012

\section{Pacific Northwest}

NATIONAL LABORATORY

Proudly Operated by Battelle Since 1965 


\title{
DISCLAIMER
}

This documentation was prepared as an account of work sponsored by an agency of the United States Government. Neither the United States Government nor any agency thereof, nor Battelle Memorial Institute, nor any of their employees, makes any warranty, express or implied, or assumes any legal liability or responsibility for the accuracy, completeness, or usefulness of any information, apparatus, product, or process disclosed, or represents that its use would not infringe privately owned rights. Reference herein to any specific commercial product, process, or service by trade name, trademark, manufacturer, or otherwise does not necessarily constitute or imply its endorsement, recommendation, or favoring by the United States Government or any agency thereof, or Battelle Memorial Institute. The views and opinions of authors expressed herein do not necessarily state or reflect those of the United States Government or any agency thereof.

\author{
PACIFIC NORTHWEST NATIONAL LABORATORY \\ operated by \\ BATTELLE \\ for the \\ UNITED STATES DEPARTMENT OF ENERGY \\ under Contract DE-AC05-76RL01830
}

Printed in the United States of America

Available to DOE and DOE contractors from the Office of Scientific and Technical Information,

P.O. Box 62, Oak Ridge, TN 37831-0062;

ph: (865) 576-8401, fax: (865) 576-5728

email: reports@adonis.osti.gov

Available to the public from the National Technical Information Service,

U.S. Department of Commerce, 5285 Port Royal Rd., Springfield, VA 22161

ph: (800) 553-6847, fax: (703) 605-6900

email: orders@ntis.fedworld.gov

online ordering: http://www.ntis.gov/ordering.htm 
PNNL-21576

\section{Analysis of Hanford-based Options for Sustainable DOE Facilities on the West Coast}

WM Warwick

June 2012

Prepared for

U.S. Department of Energy

under Contract DE-AC05-76RL01830

Pacific Northwest National Laboratory

Richland, Washington 99352 



\section{Summary}

Large-scale conventional energy projects ${ }^{1}$ result in lower costs of energy (COE). This is true for most renewable energy projects as well. The Office of Science is interested in its facilities meeting the renewable energy mandates set by Congress and the Administration. Those facilities on the west coast include a cluster in the Bay Area of California and at Hanford in central Washington State. Land constraints at the California facilities do not permit large scale projects. The Hanford Reservation has land and solar insolation available for a large scale solar project as well as access to a regional transmission system that can provide power to facilities in California.

The premise of this study is that a large-scale solar project at Hanford may be able to provide renewable energy sufficient to meet the needs of select Office of Science facilities on the west coast at a COE that is competitive with costs in California despite the lower solar insolation values at Hanford. The study concludes that although the cost of solar projects continues to decline, estimated costs for a large- scale project at Hanford are still not competitive with avoided power costs for Office of Science facilities on the west coast. Further, although it is possible to transmit power from a solar project at Hanford to California facilities, the costs of doing so add additional costs. Consequently, development of a largescale solar project at Hanford to meet the renewable goals of Office of Science facilities on the west coast is currently uneconomic. This may change as solar costs decrease and California-based facilities face increasing costs for conventional and renewable energy produced in the state. PNNL should monitor those cost trends.

In parallel to this study, the Mission Support Alliance completed a similar study of generating options that could be developed in the Mid-Columbia area to support Hanford's future mission. This study concluded the best renewable resource option was to utilize abundant wheat straw to produce power or liquid fuel. The results of this study are compared to projects in the United Kingdom (UK) that use wheat straw for power generation to conclude that this is a practical option, although project economics are still unclear. If proposals to utilize wheat straw proceed, they should be monitored by the Pacific Northwest National Laboratory (PNNL) for potential applicability to meet Office of Science renewable goals.

Although prospects for an economic project at Hanford were not supported in our analysis, trends in project costs recommend revisiting this opportunity in the future.

${ }^{1}$ Considered to be at least $200 \mathrm{MW}$ for this analysis 


\section{Contents}

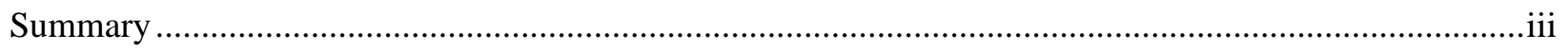

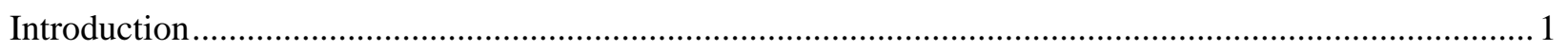

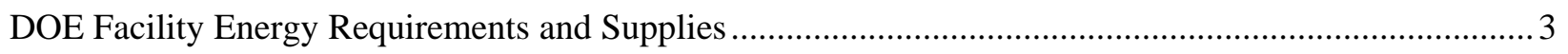

Facility Renewable Obligations and Options........................................................................................ 7

Supplying Power to DOE Facilities in California................................................................................... 11

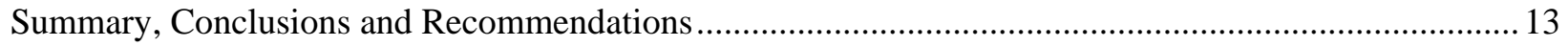

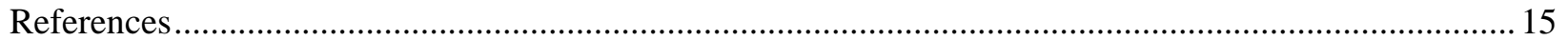




\section{Tables}

Table 1: Average (2010/2011) Annual Power Supply and Source ....................................................... 4

Table 2: Renewable Energy Requirement, per California Facility ...................................................... 4

Table 3: Expected Facility Power and Renewable Energy Requirements ................................................. 7

Table 4: Projected Capital and Power Costs for Prospective Solar Projects in 2014 and 2017................... 8 


\section{Introduction}

The Department of Energy (DOE) provides national and international leadership in the energy field. It is supported in its efforts by a network of national laboratories, including five laboratories and associated facilities on the west coast under the Office of Science:

- Pacific Northwest National Laboratory (PNNL)

- Lawrence Berkeley National Laboratory (LBNL)

- $\quad$ Lawrence Livermore National Laboratory (LLNL)

- $\quad$ Site 300 (S300)

- Stanford Linear Accelerator Center (SLAC).

Collectively, these five facilities had an average power requirement of 880,000 Megawatt hours (MWh) over the 2010 through 2011 period. To meet the renewable energy mandates in the Energy Policy Act of 2005 (EPAct) and Executive Order (EO) 13423; these facilities need to procure 7.5\% of their electricity from renewable sources by and after 2013, or roughly 81,000 MWh. Delivered power from renewable sources will also contribute to greenhouse gas reduction targets in Executive Order 13514. Thus far, none of these facilities appear to be on track to achieve this goal, in part, because of the higher cost of renewable energy compared to conventional sources and the focus of facility management on the bottom line. Consequently, PNNL was asked to evaluate opportunities that may exist to take advantage of the land and other resources at the Hanford Nuclear Reservation to develop a "utility scale" renewable resource that capitalizes on the inherent economies of scale of large projects to provide power at lower cost. The objective of this evaluation is to provide an estimate of the cost of power from reasonably available options at Hanford, as well as a discussion of how power from a single large project at Hanford could be used to satisfy the renewable requirements of facilities in California, as well as locally. 


\section{DOE Facility Energy Requirements and Supplies}

The size of a Hanford-based renewable energy project to meet the renewable requirements of the subject facilities is a function of multiple variables: future load growth, the renewable energy goal of the facility and/or Office of Science, projected cost of renewable energy, and transmission capacity from the Pacific Northwest to California facilities. The power supply situation for each facility is different because of their location and utility provider. The four California facilities receive power procured by the Western Area Power Administration (WAPA). The Hanford reservation receives power from the Bonneville Power Administration (BPA). PNNL is served by a local utility that receives the majority of its power from BPA.

WAPA and BPA are Federal power marketing administrations (PMAs) under DOE. There are several PMAs; each was inspired by the Tennessee Valley Authority (TVA), which was created during the Great Depression. Broadly speaking, PMAs are responsible for oversight of Federal hydropower projects that have multiple purposes, typically flood control, irrigation, and power generation. Political support for a Federal corporation with broad authorities waned after TVA was created; consequently, as other PMAs were created, their authorities were incrementally reduced. BPA is responsible for selling the output of Federally owned hydropower projects on the Columbia River, and coordinating operation of these along with other project owners in the U.S. and Canada. Power from the Federally owned projects is pooled and sold to various customers based on a standard rate. As a practical matter, WAPA's power obligation is to provide electricity to selected customers that are entitled to an "allocation" of the power output from Federal hydropower facilities. WAPA does not own these facilities, but is the only authorized agent to sell the power from them. The reality of WAPA's power supply obligations is more complicated because the power it has to "allocate" and the customers it serves are unique to specific hydropower projects and the legislation that authorized those projects. This contrasts with the way BPA markets its power from the combined generation of Federal projects on the Columbia River. PMA power costs are low because the projects were constructed decades ago, hydropower projects have low operating costs, and the authorizing legislation specified that power be sold “at cost” rather than market rates.

Administratively, WAPA operates through regional offices that have similar geographic scope as the hydropower projects managed by the office. The resources supplying the California DOE facilities are managed by the Sierra Nevada Region office in Folsom, California, utilizing resources from the Central Valley Projects (CVP) in northern California. BPA is headquartered in Portland, Oregon and has regional offices in the four northwest states to serve customers in Oregon, Washington, Idaho and western Montana.

Not surprisingly, the demand for access to low cost power from the PMAs exceeds the available capacity. BPA and WAPA address this problem differently; although in both cases, they are legally obliged to provide power on a preferential basis to selected customers, typically not-for-profit utilities managed by a body elected by its customers ("publicly-owned" versus "investor-owned" utilities). For WAPA, project output is "allocated" to selected customers that meet criteria established in the project authorization legislation and subsequent contract re-negotiations. The California DOE customers are "requirements" customers of WAPA with an associated allocation. Because the WAPA allocation doesn't provide for $100 \%$ of any of the site's power requirements, WAPA is obligated to meet their requirements by 
supplementing its allocation with purchases from other sources. As a result, the facilities receive a portion of their power supply that is at a relatively fixed, low cost, and the rest at a price that varies with wholesale power market prices. Accordingly, the average cost of power for each facility is lower than alternative supplies, but the cost of power above the WAPA allocation is at market rates. Consequently, displacing supplemental power purchases results in disproportionately greater energy bill savings than replacing power supplied from WAPA. Currently, WAPA provides supplemental power from competitively supplied resources. If requested by its customers, it can obtain supplies from available renewable sources. WAPA also arranges for transmission of supplemental power it provides to each requirements customer, and integrates those purchases with generation from resources it controls.

Procurement of power for DOE facilities in California is managed by the DOE Federal Energy Management Program. It has directed WAPA to purchase supplemental power collectively for all facilities for ease of administration of the contract. The average annual use at each facility and the share provided from the WAPA CVP allocation is indicated in Table 1.

Table 1: Average (2010/2011) Annual Power Supply and Source

\begin{tabular}{|l|r|l|r|l|}
\hline LAB & Total MWh & $\begin{array}{l}\text { CVP } \\
\text { MWh }\end{array}$ & Supplemental & $\begin{array}{l}\text { \% } \\
\text { CVP }\end{array}$ \\
\hline LBNL & 80,411 & 17,356 & 63,055 & 21.60 \\
\hline LLNL & 393,952 & 85,032 & 308,920 & 21.60 \\
\hline Site 300 & 13,283 & 2,867 & 10,416 & 21.60 \\
\hline SLAC & 188,947 & 40,783 & 148,164 & 21.60 \\
\hline Total & $\mathbf{6 7 6 , 5 9 4}$ & $\mathbf{1 4 6 , 0 3 8}$ & $\mathbf{5 3 0 , 5 5 6}$ & $\mathbf{2 1 . 6 0}$ \\
\hline
\end{tabular}

Although the EPAct and EO renewable goals are agency goals, rather than facility specific ones, there is an expectation within DOE that each facility will make good faith efforts to meet or exceed their share of the goal to demonstrate agency leadership. The EPAct goal for 2013 and thereafter is currently 7.5\%. If that obligation is spread across each California facility, the obligation would be as shown in Table 2.

Table 2: Renewable Energy Requirement, per California Facility

\begin{tabular}{|c|r|r|}
\hline LAB & $\begin{array}{c}\text { Total } \\
\text { MWh }\end{array}$ & $\begin{array}{c}\mathbf{7 . 5 \%} \\
\text { Goal - } \\
\text { MWh }\end{array}$ \\
\hline LBNL & 80,411 & 6,031 \\
\hline LLNL & 393,952 & 29,546 \\
\hline Site 300 & 13,283 & 996 \\
\hline SLAC & 188,947 & 14,171 \\
\hline Total & $\mathbf{6 7 6 , 5 9 4}$ & $\mathbf{5 0 , 7 4 5}$ \\
\hline
\end{tabular}

To facilitate comparison of the goal to prospective renewable energy project capacities, it is useful to translate energy consumption (MWh) into annual average capacity in terms of megawatts (MWs) equivalents. The 50,745 MWh goal, therefore, requires 5.8 MWs of generating capacity operating 
continuously for 1 year. A biomass generator and landfill-gas-fired power plant of that size could supply the necessary renewable energy as long as it wasn't shut down for maintenance or any other reason. Generation interruptions from any source require a larger project to make up the "lost” generation. Intermittent renewable sources, such as wind and solar require much larger projects because they only provide power part of the time. For example, a 1-MW solar array operating one-fifth of the time (a 20\% “capacity factor”) will produce 1,752 MWh, instead of the 8,760 MWh it would produce if the sun shone continuously at the same intensity. The capacity factor for solar at Hanford is approximately 15\% depending on the type of solar panels used, how they are arranged and other factors. To produce one “average” MW of power annually (8,760 MWh), almost 7 times more MWs of solar photovoltaic (PV) capacity would need to be installed. In other words, the 5.8 MW "average” required to meet the $7.5 \%$ goal would require installation of $38 \mathrm{MWs}$ of solar PV at Hanford.

The loads for DOE facilities in Washington State include those for PNNL and the Hanford Site. Current loads are 205,000 MWh; however, these will increase significantly. A vitrification plant is currently under construction at Hanford to treat hazardous wastes from previous nuclear waste operations at the site. This plant will encapsulate hazardous material in glass blocks. The plant is expected to be operational by the end of the decade and use a significant amount of electricity and natural gas in its operations. The PNNL campus, which is located outside the DOE Hanford Site, and associated loads are served by the City of Richland, a municipal utility customer of BPA. The DOE Hanford Site operation is a full requirements customer of BPA and receives its power directly from BPA's transmission system. The vitrification plant under construction at Hanford is expected to add roughly 70 MWs of demand to the DOE (PNNL and Hanford) power requirements. Hanford has arranged for this new power requirement to be provided by BPA at preferential rates, although Hanford is also exploring other power supply options such as on-site natural gas power generation. The City of Richland is also a full requirements customer of BPA, but it is served separately from Hanford. 


\section{Facility Renewable Obligations and Options}

For the purposes of this document, the applicable loads and renewable energy targets are summarized in Table 3. Note that the PNNL data includes expected demand for Hanford and the planned vitrification facility, which should be fully operational by or before the end of the decade.

Table 3: Expected Facility Power and Renewable Energy Requirements

\begin{tabular}{|l|r|r|}
\hline LAB & \multicolumn{1}{|c|}{$\begin{array}{l}\text { Total } \\
\text { MWh }\end{array}$} & $\begin{array}{l}\text { 7.5\% Goal } \\
\text { - } \mathbf{\text { MWh }}\end{array}$ \\
\hline LBNL & 80,411 & 6,031 \\
\hline LLNL & 393,952 & 29,546 \\
\hline Site 300 & 13,283 & 996 \\
\hline SLAC & 188,947 & 14,171 \\
\hline $\begin{array}{l}\text { PNNL/Hanford } \\
\text { (in 2020) }\end{array}$ & 818,200 & 61,365 \\
\hline Total & $\mathbf{1 , 4 9 4 , 7 9 3}$ & $\mathbf{1 1 2 , 1 0 9}$ \\
\hline
\end{tabular}

The 112,000 MWhs required to meet the $7.5 \%$ renewable goal is equal to roughly one 13-MW power plant operating continuously. This compares to the roughly 5.8 MW requirement noted previously, which is needed just for California facilities. The distinction is important, because a project at Hanford to serve PNNL/Hanford loads would not require transmission off-site.

Issues with siting wind turbines or developing geothermal potential on the Hanford Site and the relative isolation of the site from traditional woody biomass resources have been noted as limiting factors in prior studies by the National Renewable Energy Laboratory (Dean and Haase 2008) and PNNL (Wilson and Warwick 2011) for Hanford projects. The solar potential at Hanford is only moderately good; however, resource availability is only one ingredient for a successful project. Two other important ingredients are adequate and available land and access to transmission; Hanford has both. Ongoing economies in the solar photovoltaic industry are making projects in areas outside the desert southwest increasingly competitive with retail power prices. For this study, a leading solar PV firm, SunPower, was asked for an estimate of projected construction costs and contract power prices for large-scale projects at two future dates $^{2}$. Their estimates are summarized in Table 4.

\footnotetext{
${ }^{2}$ Projected Capital and Power Cost for Prospective Solar Projects in 2014 and 2017. Email message from Kevin Prince (SunPower) to W. Michael Warwick (Pacific Northwest National Laboratory), April 24, 2012.
} 
Table 4: Projected Capital and Power Costs for Prospective Solar Projects in 2014 and 2017

\begin{tabular}{|r|r|c|c|}
\hline Year & $\begin{array}{l}\text { PV } \\
\text { Size } \\
(\mathrm{MW})\end{array}$ & $\begin{array}{l}\text { Capital Cost } \\
(\$ / \text { watt })\end{array}$ & PPA Price $(\$ / \mathrm{kWh})$ \\
\hline \multirow{2}{*}{2014} & 40 & $\$ 3.05$ & $\$ 0.110$ \\
\cline { 2 - 4 } & 100 & $\$ 2.90$ & $\$ 0.100$ \\
\hline \multirow{2}{*}{2017} & 40 & $\$ 2.60$ & $\$ 0.115$ \\
\cline { 2 - 4 } & 100 & $\$ 2.40$ & $\$ 0.105$ \\
\hline
\end{tabular}

Estimates of this type are subject to a variety of assumptions. In this case, the expiration of renewable tax credits prior to 2017 is assumed to be partly offset by decreased system costs. The size of projects necessary for scale economies has matured along with the industry. Given the solar potential at Hanford, approximately 85 MWs of solar capacity is needed to provide the 112,109 MWhs needed to meet the 7.5\% renewable goal for all west coast DOE facilities. A project of this size could attract long- term power purchase price bids in the $10 \mathrm{cent} / \mathrm{kWh}$ range, which is well above the current BPA rate available to Hanford and likely to be almost twice that rate by 2017, even assuming some escalation in BPA's rates.

Historically, power costs in California have been significantly higher than in the Northwest because of the large hydropower resource. If this inter-regional price differential persists, it may be possible for the effective price of solar from Hanford to be competitive with the average cost of power across all west coast DOE facilities. To use a simple example, if power for PNNL cost 5 cents/kWh, and power for California facilities cost 15 cents/kWh, the average between the two would be 10 cents/kWh. On paper, at least, DOE would be indifferent to the cost of power from a solar project or conventional suppliers. This was the assumption that formed the basis for this assessment; namely that DOE would be willing to pay more than the prevailing power cost at one facility if the cost could be offset at other facilities by the lower power cost from a larger power project...

Although California power costs were especially high after the state "deregulated," this was a period during which power markets were deliberately manipulated to produce extremely high prices. A number of steps have been taken in the intervening years to limit that risk. Currently, low cost natural gas makes it difficult to sustain high power prices, and future price projections for power costs in California are in the 5 to 6 cent/kWh range. This is similar to prices in the Northwest, which will also be dependent upon natural-gas generation to meet growing loads now that the available hydropower resource is fully utilized. Consequently, solar power that costs 10 to 11 cents/kWh to produce at Hanford is not competitive with expected conventional power costs in California.

The original mission at Hanford is ending, and future activities will focus on cleanup of the site and vitrification of the legacy waste. These activities will require a much smaller workforce. However, the infrastructure that remains at Hanford and in the region, along with the skilled workforce, present an opportunity for redeployment in other, energy related industries. The Mid-Columbia Energy Initiative (MCEI) is a regional organization with an objective of facilitating the transition to these new industries by working collaboratively with private and government stakeholders to identify new industries and new 
ways to use stakeholder resources, including land available on and near Hanford, as well as local port, freeway and rail facilities. One option the MCEI identified is to develop new energy sources to meet the new energy requirements on Hanford. A recently released a report by DOE (DOE/RL -2011-117) evaluated various options and opportunities, including development of solar energy options. The report examined the feasibility of a full range of "clean energy" options that could be available by the end of the decade. The "clean" technologies evaluated included natural gas and nuclear, as well as more conventionally defined clean generating sources. The report concluded that the use of biomass, especially locally available wheat straw from the region's extensive wheat farms, provided the best conventional renewable energy option.

Wheat farming is well established in the area surrounding Hanford because it is the commercial crop best suited to the soil, weather and market conditions that exist. After harvest of the wheat berries, the stalk is left in the field. Because of the dry climate, tilling the stalks in provides little value for soil or moisture retention and has no value as a crop nutrient. As a result, it is a nuisance and traditionally has been burned to remove it from fields for future cultivation. Therefore, it is a true waste product. The DOE report estimated the available material at 7.5 million U.S. tons. The DOE report indicates the straw is currently burned in situ, therefore, utilization for fuel would require collection, packaging in bales or other form, and transportation from fields scattered across an area 100 miles from Hanford, presumably by truck, although both barge and rail access to Hanford are options.

The DOE report focused on alternative energy sources that could be sited at Hanford as part of the DOE Asset Revitalization Initiative intended to assist in economic development in regions near DOE sites and respond to an increase of approximately $100 \mathrm{MW}$ in near-term demand for electricity in the Pacific Northwest. It concluded a liquid-fueled power plant using fuels derived from liquefaction of natural gas and methane derived from biomass sources is the best option. However, it notes that liquefaction plants of the scale required have not been commercially developed, although several have been proposed. The report also notes that once a liquid fuel is produced, it has value as a transportation fuel, which is generally greater than the alternative cost of fuel to generate power, be that either natural gas or syngas from biomass. In other words, if liquid fuel is manufactured, sale as a transportation fuel would produce greater profits than would use to produce thermal energy or power.

The syngas production process recommended in the DOE report employs anaerobic digestion. Simply stated, the wheat straw would be emulsified with water and allowed to ferment in an anaerobic environment. Fermentation gases would contain methane (biogas) that could be used in power generation. The report also discusses a new approach, BioChemCat, which can divert alcohol produced from fermentation into further processes that yield chemicals or liquid fuels through catalytic conversion. This is the approach favored in the DOE report. Anaerobic digestion and catalytic conversion of alcohols are both conventional processes with little technology risk. The combination, however, has not been demonstrated at commercial scale.

The focus of this report is renewable power generation to serve west coast DOE facilities, so the commercial readiness of anaerobic digestion for methane production as suggested in the DOE report is our the primary interest in that report. Anaerobic digestion projects are relatively common. Columbia Biogas is planning to develop such a project in Portland, Oregon to both process urban food wastes and produce power for sale into the wholesale power market. According to Columbia Biogas, there are over 
150 plants in the U.S. and nearly 7,500 in Europe (Columbia BioGas 2012). The plant is expected to cost $\$ 55$ million and be operational in 2013. The economics depend on a long-term power purchase agreement for the power output, as well as revenues from waste disposal and sale of co-products. Production capacity by 2018 is expected to be 5 MWs using 70,000 tons of waste material. The anaerobic digestion technology specified for the plant is based on commercial projects in Europe. Because this process relies on handling liquid materials, Columbia Biogas indicated it has more in common with the waste processing equipment used in sewage plants than conventional biomass generating plants. This kind of equipment is readily available, which also reduces construction and operating risk. Based on published cost and production values, the Columbia Biogas plant costs an average of \$11 million per MW of generating capacity (Columbia BioGas 2012). The DOE report estimated costs for a plant utilizing anaerobic digestion of wheat straw with the capability to produce power initially and liquid fuels with additional plant upgrades at $\$ 135$ million (in 2007 dollars). Approximately $44 \%$ of these costs would be associated with production of 75 MWs of power, resulting in a cost per MW of capacity of roughly \$ 0.8 million. That is significantly different than the costs provided by Columbia Biogas. That difference may be caused by economies of scale and other factors (such as financing and permitting costs).

The DOE report estimate of wheat straw needed for a 75-MW scale project is 575,000 U.S. tons annually. It estimated delivered costs of $\$ 65$ to $\$ 100$ per ton, including a $\$ 5$ per ton payment for farmers to bale the straw for collection. Although North American examples of wheat straw powered generators are lacking, Energy Power Resources, Limited (EPR) of the UK has operated a 38-MW plant near Ely, fueled primarily by wheat straw since June 2004 (EPR 2012). This plant uses 200,000 “tonnes” of straw annually in a conventional steam boiler generator. However, actual statistics for the plant are somewhat unclear from publicly available information. First, the quantity is provided in terms of "tonnes;" however, it isn't clear if these are UK tonnes (long tons) or metric tonnes. For comparison, 200,000 UK "long” tons is equal to 196,841 U.S. "short" tons, but 220,462 metric tonnes. Second, although wheat is grown extensively in the area of the Ely plant, it is not produced in sufficient quantities to assure reliable, economic supply to the plant, which has to rely on other fuel sources, including natural gas. Publicly available data suggests wheat straw may provide less than $90 \%$ of total fuel for the plant (EPR 2012). Regardless, the quantities reported are consistent with the 575,000 U.S. tons figure suggested in the DOE report: a quantity that should be readily available from sources near Hanford.

The Ely power plant is competitive with power from other sources in the deregulated power market of the UK. However, it is considered a "clean energy" plant, and therefore, benefits from renewable energy incentives and carbon credits that offset the inherent cost disadvantages of its small scale and unique fuel supply. The plant pays between 28 and 30 Great Britain Pounds (GBP) for each tonne of straw ${ }^{3}$. At current exchange rates, that is equal to about $\$ 42$ to $\$ 48$. Retail power prices to large customers in the UK currently average around $\$ 83 / \mathrm{MWh}$, excluding transmission and distribution costs to the customer.

\footnotetext{
${ }^{3}$ Information provided in a telephone conservation between Mike Edwards, MI Edwards Engineering, Bradon Suffolk UK and W. Michael Warwick, Pacific Northwest National Laboratory
} 


\section{Supplying Power to DOE Facilities in California}

The cost of power is only one component of power cost to a specific facility. The other costs are transmission and distribution to the site and costs to "firm and shape" the power so that the supply of power from a generator "follows" customer loads on an instant basis (shaping service) and does so reliably (firming service). The premise of this analysis is that renewable power can be produced at Hanford and transmitted to DOE facilities in California at a lower cost than it can be procured by those facilities locally. Hanford and the DOE facilities are served by two different PMAs in two different regional transmission organizations (RTOs) and control areas. Transmitting power from Hanford would require coordination of transmission by BPA at Hanford and with WAPA in California.

Typically, the ability to transmit power from one area to another requires the power buyer (or more typically its power supplier) to arrange for transmission access by reserving transmission capacity in the appropriate RTO areas. Transmission capacity is in high demand and reservations necessary to complete a transaction may not be available. Generally, demand for transmission from the Northwest to California exceeds available capacity much of the year; however, select Federal facilities in California have rights to transmission capacity on the California-Oregon Transmission Project (COTP), a high-voltage transmission line from the California-Oregon border (COB) into the California transmission system. This right entitles DOE and Federal wildlife refuges to approximately 100 MWs of transmission capacity on the COTP (depending on line ratings at the time). WAPA manages this entitlement on behalf of the owners. According to Federal Energy Regulatory Commission (FERC) rules, if the capacity is not being used by the owners, it has to be offered to other users. In general, the capacity is not used and is made available to other users. It is presumed that this capacity could be reserved to transmit power from Hanford to the DOE facilities in California. That has been confirmed, in concept, in email exchanges with WAPA staff in Sacramento as well as with FEMP staff. However, power would still need to be transmitted to COB, presumably through arrangements with BPA. That process is initiated with BPA through a transmission service request (TSR). TSRs are processed on a first-come basis. Based on conversations with BPA, there are over 300 TSRs for access to the path required to transmit power from the Hanford area to COB. Consequently, it appears firm transmission capacity is not currently available; however, capacity may become available in the future.

All RTOs or control area operators have an interconnection process for prospective generators to request a reservation of transmission capacity. For a project at Hanford, an interconnection request would also be required. That process involves three studies; a feasibility study, interconnection impact study, and a facilities study. There are fees associated with the interconnection application and each of the studies. These vary depending on the request, but currently would add at least $\$ 200,000$ to the cost of project planning. Completion of the studies does not guarantee interconnection. If interconnection is determined to be feasible, a TSR would be submitted. TSRs also require fee payments, even to sit in a long queue with other prospective users. Transmission fees vary based on the request, but currently run about $\$ 13,000$ per month. In addition to the transmission fee, there are ancillary transmission service fees. BPA estimates these would currently be roughly \$12 per MW per month, or roughly 1.2 cents per kWh. Once power was delivered to COB, WAPA would provide transmission to the DOE facilities at little additional expense over and above its current transmission costs. 
Integrating power from Hanford to California facilities from an intermittent renewable power project, such as the solar farm evaluated previously, will still require firming and shaping using other generation to provide facilities with reliable power when it is needed. Firming and shaping services could be provided with the renewable power from the Northwest or secured in California from spot market purchases or other sources. The market price for this service would depend on the time of day and year when power was exported to California. Nevertheless, firming and shaping could be expected to add several cents to the cost of power delivered to California facilities.

Power from a biomass facility at Hanford would be produced more or less continuously. Therefore, it wouldn't require as much power for firming and shaping, and delivered power costs would be significantly lower, as would the cost of transmission per $\mathrm{kWh}$ because a biomass project would have a much higher capacity factor than a solar farm. Nevertheless, some shaping would be required, although it could be in the form of reduced supplemental power purchases by WAPA or resale of generation above the needs of the California facilities.

To date, WAPA has not been asked to purchase renewable power for its DOE customers in California, although it has been providing renewable energy credits (RECs) to them to meet applicable renewable energy requirements. Consequently the cost of renewable energy supplied by WAPA isn't available for comparison. According to FEMP staff, WAPA has been approached about facilitating development of on-site projects, such as solar photovoltaics, for at least one DOE location in California. 


\section{Summary, Conclusions and Recommendations}

This report was requested to evaluate the option of using renewable resources and land at the DOE Hanford Site to develop a large-scale project that could supply power to DOE and laboratory facilities in Richland and California to help the Office of Science meet the requirements of various executive orders and agency goals. The premise of the report is that it may be less expensive to develop a single large project at Hanford, where land is readily available to capture the economies of scale associated with larger projects. Power from Hanford could be transmitted to facilities in California through BPA's transmission grid to the Oregon border, where it would be delivered to a transmission line managed by WAPA that has capacity dedicated to DOE. Previous studies of renewable resource potential at Hanford identified solar photovoltaics as the best renewable resource option (Dean and Haase 2008), although not one competitive with current power rates. A later study by DOE looking at power options for new facilities expected at Hanford by or before 2020 identified biomass from wheat straw as the best option for that purpose.

The focus of this report is on near-term actions that can be taken to satisfy the renewable power requirements of Office of Science facilities. Despite falling costs for solar systems, power from a large solar project at Hanford is not competitive with conventional power costs for facilities in either Washington or California. Further, transmission on the BPA system to the WAPA system in California is not readily available and would add additional costs to the already uneconomic price of solar power. Therefore, we conclude that providing solar power from a large project at Hanford to meet DOE facility renewable goals is impractical at this time. The DOE report that concluded biomass from wheat straw may be economic suggests that option should be explored in conjunction with Hanford as it evaluates power supply options for its future operations, despite the fact it may not provide renewable power for 5 to 10 years.

The cost of power from solar systems is projected to continue to decline. Economies of scale will still apply and, therefore, large solar projects will still provide lower cost power than smaller ones. Large projects will also require large land areas close to high voltage transmission lines. Consequently, Hanford may still prove to be a good location for a large solar project. PNNL should monitor further efforts in the area to pursue power from wheat straw or other renewable sources to meet future power needs at Hanford. If those proceed, PNNL should revisit the renewable energy requirements of California DOE facilities and prospects for transmitting power from Hanford to them. 


\section{References}

Columbia Biogas. 2012. Renewable Energy from Anaerobic Digestion of Food Waste. Presentation to Oregon Energy Forum Breakfast Meeting, February 29, 2012, Portland, Oregon

Dean, J. and S. Haase. 2008. Transformational Energy Action Management PV, CSP, and Biomass Feasibility Study Final Report. U.S. Department of Energy, Federal Energy Management Program, National Renewable Energy Laboratory, Golden, CO.

DOE- U.S. Department of Energy, Richland Operations Office. 2011. Mid-Columbia Clean Energy Feasibility Assessment. Rev. 0, DOE/RL - 2011 - 117. Prepared for the U.S. Department of Energy, Office for Environmental Management by the Mission Support Alliance, Richland, WA.

Electric Power Resources (EPR). 2012. Ely Power Station. New York. Accessed at http://www.eprl.co.uk/assets/ely/overview.html. in June 2012.

Wilson R.W. and M. Warwick, Northwest Energy Initiative Brief for DOE Hanford. Presentation by U.S. Army Corp of Engineers and Pacific Northwest National Laboratory to U. S. Department of Energy - Hanford Operations, April 12, 2011. 